Prepared in cooperation with Colorado State University

\title{
Modeled Streamflow Metrics on Small, Ungaged Stream Reaches in the Upper Colorado River Basin
}

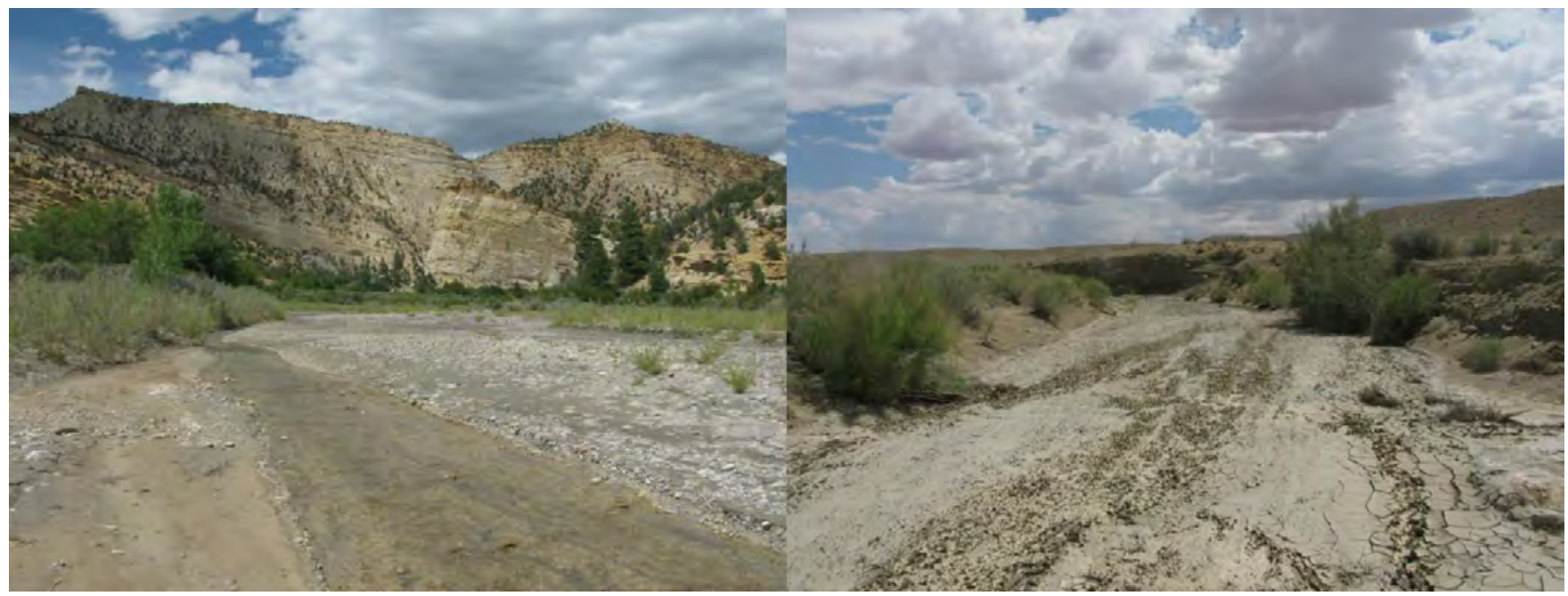

Data Series 974 
Cover. Left: Henrieville Creek near Henrieville, Utah, a perennial stream. Photograph taken by Joel Shute and Mark Paglierani (2012). Right: Coyote Creek, Utah, near Page, Arizona, an intermittent stream. Photograph taken by Joel Shute and Mark Paglierani (2012). 


\section{Modeled Streamflow Metrics on Small, Ungaged Stream Reaches in the Upper Colorado River Basin}

By Lindsay V. Reynolds and Patrick B. Shafroth

Prepared in cooperation with Colorado State University

Data Series 974 


\title{
U.S. Department of the Interior SALLY JEWELL, Secretary
}

\section{U.S. Geological Survey \\ Suzette M. Kimball, Acting Director}

\author{
U.S. Geological Survey, Reston, Virginia: 2016
}

For more information on the USGS - the Federal source for science about the Earth, its natural and living resources, natural hazards, and the environment—visit http://www.usgs.gov or call 1-888-ASK-USGS.

For an overview of USGS information products, including maps, imagery, and publications, visit http://www.usgs.gov/pubprod/.

Any use of trade, firm, or product names is for descriptive purposes only and does not imply endorsement by the U.S. Government.

Although this information product, for the most part, is in the public domain, it also may contain copyrighted materials as noted in the text. Permission to reproduce copyrighted items must be secured from the copyright owner.

Suggested citation:

Reynolds, L.V., and Shafroth, P.B., 2016, Modeled streamflow metrics on small, ungaged stream reaches in the Upper Colorado River Basin: U.S. Geological Survey Data Series 974, 11 p., http://dx.doi.org/10.3133/ds974.

ISSN 2327-638X (online) 


\section{Acknowledgments}

The U.S. Bureau of Reclamation WaterSMART program through the Southern Rockies Landscape Conservation Cooperative provided financial support (Reclamation Grant \#R11AC81525). Thanks to LeRoy Poff for providing support and discussions on development of the data.

Financial support also came from USGS WaterSMART funds for ecological flows work in the Colorado River Basin. Thanks to Michael O'Donnell for access to USGS Fort Collins Science Center high-capacity machines to run flow accumulation rasters and random forest projections. Tammy Fancher and Drew Ignizio assisted with figure creation and metadata creation and editing. Finally, thanks to Greg Auble, and Michael O'Donnell for helpful comments and discussion on earlier drafts. 



\section{Contents}

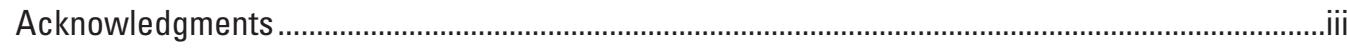

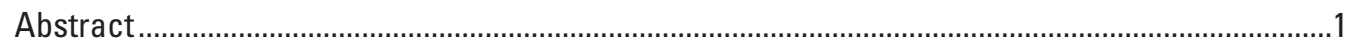

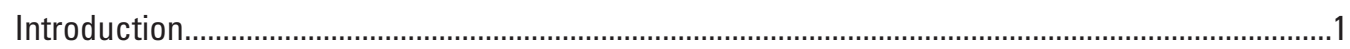

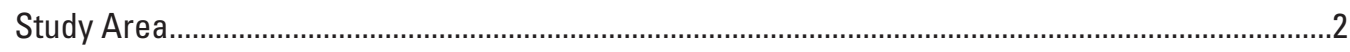

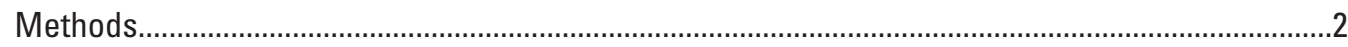

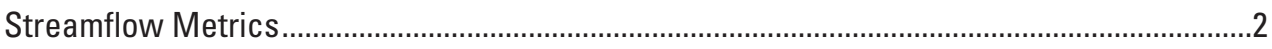

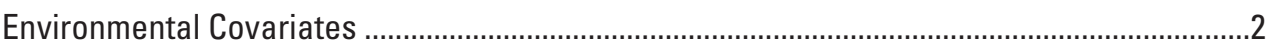

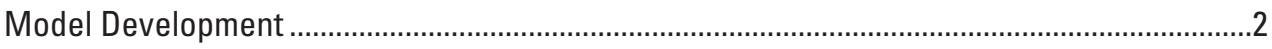

Model Projection to Ungaged Streams.................................................................................

Predicting Streams Threatened with Intermittency ………………..........................................

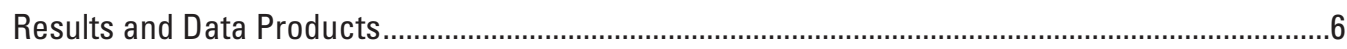

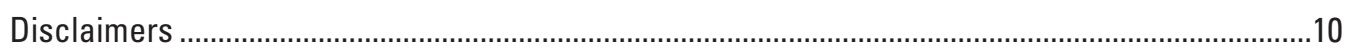

Summary

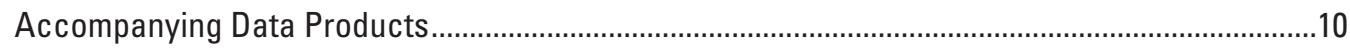

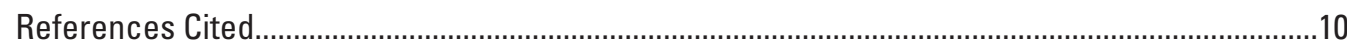

\section{Figures}

1. Map showing the Upper Colorado River Basin study area elevation, major rivers, and study gage locations .........................................................................................

2. Map showing predicted values of specific mean daily flow multiplied by 1,000 for small streams in a small area of the Upper Colorado River Basin .....................................8

3. Map showing predicted intermittency status of small stream reaches based on current streamflow metrics in the Upper Colorado River Basin: perennial, threatened with intermittency, intermittent, or strongly intermittent

\section{Tables}

1. Streamflow metrics modeled by environmental variables in the Upper Colorado River Basin

2. Environmental variables used to predict flow metrics on gaged streams in the Upper Colorado River Basin.

3. Results of random forest models using environmental variables to predict streamflow metrics

4. Geospatial datasets of projected streamflow metrics and threatened intermittency status in the Upper Colorado River Basin. 


\section{Conversion Factors}

[Inch/Pound to International System of Units]

\begin{tabular}{lcl}
\hline \multicolumn{1}{c}{ Multiply } & By & \multicolumn{1}{c}{ To obtain } \\
\hline foot $(\mathrm{ft})$ & Length & meter $(\mathrm{m})$ \\
\hline & 0.3048 & \\
\hline square mile $\left(\mathrm{mi}^{2}\right)$ & Area & hectare $($ ha) \\
square mile $\left(\mathrm{mi}^{2}\right)$ & 259.0 & square kilometer $\left(\mathrm{km}^{2}\right)$ \\
\hline & 2.590 & \\
\hline cubic foot $\left(\mathrm{ft}^{3}\right)$ & Volume & cubic meter $\left(\mathrm{m}^{3}\right)$ \\
\hline & 0.02832 & \\
\hline $\begin{array}{c}\text { cubic foot per second }\left(\mathrm{ft}^{3} / \mathrm{s}\right) \\
\text { cubic foot per second per square } \\
\text { mile }\left[\left(\mathrm{ft}^{3} / \mathrm{s}\right) / \mathrm{mi}^{2}\right]\end{array}$ & Flow rate & cubic meter per second $\left(\mathrm{m}^{3} / \mathrm{s}\right)$ \\
& 0.02832 & cubic meter per second per \\
& 0.01093 & square kilometer $\left[\left(\mathrm{m}^{3} / \mathrm{s}\right) / \mathrm{km}^{2}\right]$ \\
\hline
\end{tabular}

Temperature in degrees Celsius $\left({ }^{\circ} \mathrm{C}\right)$ may be converted to degrees Fahrenheit ( ${ }^{\circ} \mathrm{F}$ ) as ${ }^{\circ} \mathrm{F}=\left(1.8 \times{ }^{\circ} \mathrm{C}\right)+32$.

Temperature in degrees Fahrenheit $\left({ }^{\circ} \mathrm{F}\right)$ may be converted to degrees Celsius $\left({ }^{\circ} \mathrm{C}\right)$ as ${ }^{\circ} \mathrm{C}=\left({ }^{\circ} \mathrm{F}-32\right) / 1.8$.

Horizontal coordinate information is referenced to the North American Datum of 1983 with an Albers projection (NAD 83 Albers). 


\title{
Modeled Streamflow Metrics on Small, Ungaged Stream Reaches in the Upper Colorado River Basin
}

\author{
By Lindsay V. Reynolds ${ }^{1,2}$ and Patrick B. Shafroth ${ }^{2}$
}

\begin{abstract}
Modeling streamflow is an important approach for understanding landscape-scale drivers of flow and estimating flows where there are no streamgage records. In this study conducted by the U.S. Geological Survey in cooperation with Colorado State University, the objectives were to model streamflow metrics on small, ungaged streams in the Upper Colorado River Basin and identify streams that are potentially threatened with becoming intermittent under drier climate conditions. The Upper Colorado River Basin is a region that is critical for water resources and also projected to experience large future climate shifts toward a drying climate. A random forest modeling approach was used to model the relationship between streamflow metrics and environmental variables. Flow metrics were then projected to ungaged reaches in the Upper Colorado River Basin using environmental variables for each stream, represented as raster cells, in the basin. Last, the projected random forest models of minimum flow coefficient of variation and specific mean daily flow were used to highlight streams that had greater than 61.84 percent minimum flow coefficient of variation and less than 0.096 specific mean daily flow and suggested that these streams will be most threatened to shift to intermittent flow regimes under drier climate conditions. Map projection products can help scientists, land managers, and policymakers understand current hydrology in the Upper Colorado River Basin and make informed decisions regarding water resources. With knowledge of which streams are likely to undergo significant drying in the future, managers and scientists can plan for stream-dependent ecosystems and human water users.
\end{abstract}

\section{Introduction}

Modeling streamflow is an important approach for understanding landscape-scale drivers of flow and estimating flows where there are no gaged records (Carlisle and others, 2010;

${ }^{1}$ Colorado State University

${ }^{2}$ U.S. Geological Survey
Murphy and others, 2012). The number of streams instrumented to measure flow are decreasing because of funding limitations (http://streamstats09.cr.usgs.gov/ThreatenedGages/ ThreatenedGages.html). In addition, with projected changes in future climate conditions, there is a need to estimate the effects of climate change on streamflow (Teng and others, 2012); therefore, modeled projections of streamflow are essential for scientists, managers, and policymakers to make informed decisions regarding water resources and stream-dependent ecosystems (Eng and others, 2013; Teng and others, 2012).

In the southwestern United States, mean annual streamflow is projected to decrease during the next century because of changing climate conditions (Seager and others, 2013). Some studies suggest strong seasonal signatures will result in increasing winter precipitation and streamflow (especially in northern latitudes) and decreasing late summer and fall precipitation and streamflow (especially in southern latitudes) because of climate change in western North America (Milly and others, 2005; Cayan and others, 2008; Colorado Water Conservation Board, 2010; Seager and others, 2013). In arid and semiarid regions of the western United States where intermittent streams are common, several studies predict that minimum flows will decrease, and the number of zero-flow days will increase in the future (Das and others, 2011; Leppi and others, 2011; Jaeger and others, 2014). Decreased minimum flows could lead some perennial streams to shift to intermittent streamflow regimes under climate-driven changes in timing and magnitude of precipitation and runoff and increases in temperature (Jaeger and others, 2014).

We focused the study on the Upper Colorado River Basin, which is a region that is not only critical for water resources but also projected to experience large future shifts towards a drier climate (Christensen and Lettenmaier, 2007; Clow, 2010; Seager and others, 2013). The Colorado River Basin is one of the most intensively managed river systems in the world and a vital water resource in the western United States supplying water for cities, agriculture, energy production, and natural ecosystems across seven states and two countries (Jerla and others 2012). This study was conducted by the U.S. Geological Survey in cooperation with Colorado State University with the objectives of producing maps of modeled streamflow metrics on small, ungaged streams in the Upper Colorado River Basin and identifying streams that 
are potentially threatened with becoming intermittent in the next century based on twentieth century hydrology and our understanding of modeled future climates. The datasets presented here build on analyses developed in a previous study by Reynolds and others (2015).

\section{Study Area}

The Upper Colorado River Basin extends from southwestern Wyoming to northern Arizona and New Mexico and includes the western one-half of Colorado and the eastern one-half of Utah (fig. 1). The headwater streams of the Upper Colorado River Basin form at high elevations in the Wind River, Uinta, Wasatch, and Colorado Rocky Mountains. Higher elevation and northern streams in the Upper Colorado River Basin are characterized by snowmelt peak runoff in the late spring that decreases to base flow in the late summer and early fall (Poff and Ward, 1989). Streams in the southern part of the Upper Colorado River Basin may experience a second streamflow peak in mid- to late summer associated with rainfall from the North American Monsoon, and this monsoon rainfall is often the primary driver of annual flow in smaller, southern Upper Colorado River Basin streams (Hereford and Webb, 1992; Ely, 1997; Gochis and others, 2006).

\section{Methods}

\section{Streamflow Metrics}

To train our models, we selected 115 streamgages with at least 8 years of data on small ( 1 st- 4 th order), unaltered streams in the Upper Colorado River Basin (fig. 1; Reynolds and others, 2015). We selected nine flow metrics that are important to low-flow stream hydrology: minimum flow coefficient of variation (CV), baseflow, zero-flow days, zeroflow months, 7-day minimum, frequency of low-flow pulses, specific minimum flow, specific mean daily flow, and intermittency (table 1). All flow metrics except intermittency were calculated using the Hydrologic Index Tool (HIT) software on the historic daily streamflow data (Olden and Poff 2003; Heasley 2006; table 1). We defined intermittency based on zero-flow days and zero-flow months and placed the streams into three categories: strongly intermittent, weakly intermittent, or perennial. Stream reaches were strongly intermittent when greater than 5 percent of months during the period of record were zero-flow months and the number of zero-flow days averaged across years was greater than 20 per year; weakly intermittent when between 0 and 5 percent of months were zero-flow months and the number of zero-flow days averaged across years was between 0 and 20 years; and perennial when the percent of zero-flow months and the number of zero-flow days averaged across years were zero. If a stream, for example, had a 20 -year period of record ( 240 months), at least 12 months of the record would have to have zero-flow days for the entire month, and an average across years of at least 20 zero-flow days per year, for the stream to qualify as strongly intermittent. The strongly intermittent stream category may also include ephemeral streams; however, we did not distinguish between strongly intermittent and ephemeral streams.

\section{Environmental Covariates}

Environmental covariates for our models were derived from Geographic Information System datasets of climate (17 datasets), soils (2 datasets), geology (13 datasets), and land cover (7 datasets) for each individual raster cell in the Upper Colorado River Basin stream network (Falcone, 2011; table 2). We used the National Hydrography Dataset Plus, version 1, flow accumulation raster (30-meter resolution) to represent stream cells in the Upper Colorado River Basin (NHDPlus, 2010). Temporal and spatial scale varied somewhat across the datasets depending on the nature of the data. Climate and soil rainfall runoff factor ( $\mathrm{R}$ factor) data were mean values for 30-year periods (climate normals) in the latter one-half of the 20th century, which overlapped with the streamgage records that were used (table 2). Soil permeability, geology, and land-cover data did not have a temporal range and were associated with their publication dates (table 2). Since the spatial scales of environmental variables were different, we used the ArcGIS raster "resample" tool to resample each variable's raster using the bilinear method to a 30-meter scale. Environmental variables were then accumulated for the upstream drainage area or a percentage of upstream drainage area was calculated for each cell as appropriate (table 2).

\section{Model Development}

We used a random forest approach to model the relationship between flow metrics and environmental variables (Cutler and others 2007). We rectified our gage site locations with the raster datasets of environmental variables for the random forests. To improve explanatory power and model fit, we implemented a model selection process where variables that fell below a calculated model improvement ratio were dropped from the model (Murphy and others 2010). We then selected the model that minimized mean square error (MSE) and maximized percentage of variation explained for each flow metric (Murphy and others 2010; Reynolds and others 2015). We assessed model fit with percentage of variation explained (pseudo- $R^{2}$ ), MSE, and a calculated $P$-value (a measure of the strength or statistical significance of a relation; smaller p-values indicate stronger relations) for the best model for each flow metric (Murphy and others 2010). To fit our models we used the "randomforest" function of R's "RandomForest" package (R 3.0.0, R Development Core Team, 2013). The model for base flow was dropped from further analysis because of poor model performance and fit (less than 


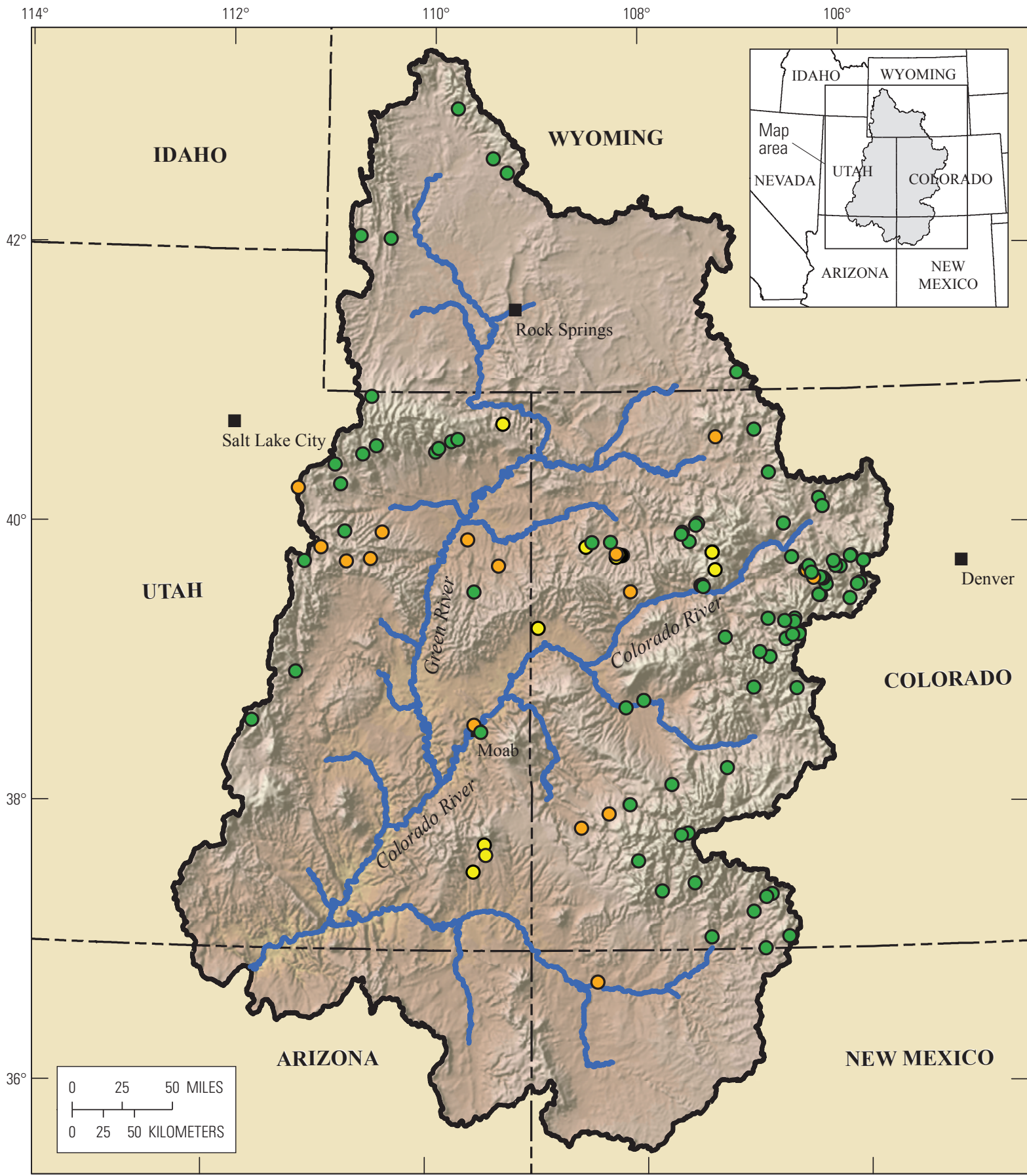

Base from U.S. Geological Survey

North America Shaded Relief, 2011

\section{EXPLANATION}

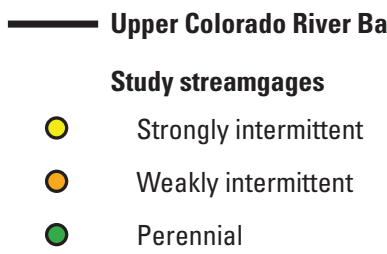

Figure 1. The Upper Colorado River Basin study area elevation, major rivers, and study gage locations (strongly intermittent, weakly intermittent and perennial). 
Table 1. Streamflow metrics modeled by environmental variables in the Upper Colorado River Basin.

[Adapted from Reynolds and others (2015). CV, coefficient of variation]

\begin{tabular}{ll}
\hline \multicolumn{1}{c}{ Streamflow metric } & \multicolumn{1}{c}{ Definition (units) } \\
\hline Minimum flow CV & $\begin{array}{l}\text { Standard deviation of annual minimum flows times } 100 \text { divided by the mean of annual minimum flows } \\
\text { (percent). }\end{array}$ \\
Base flow & $\begin{array}{l}\text { The mean of the ratios of the minimum annual flow to mean annual flow for each year times } 100 \\
\text { (dimensionless). }\end{array}$ \\
Zero-flow days & Mean annual number of zero-flow days (days/year). \\
Zero-flow months on record & $\begin{array}{l}\text { Mean of the annual minimums of a 7-day moving average for each year (cubic foot per second). } \\
\text { 7-day minimum }\end{array}$ \\
Frequency of low-flow pulses & $\begin{array}{l}\text { Mean of the annual average number of events below } 5 \text { percent of the mean flow for the entire record } \\
\text { (number of events/year). }\end{array}$ \\
Specific minimum flow & $\begin{array}{l}\text { Mean of the annual minimum flows divided by drainage area (cubic foot per second/square mile). } \\
\text { Specific mean daily flow }\end{array}$ \\
Intermittency & $\begin{array}{l}\text { Strongly intermittent, weakly intermittent, or perennial streams. See full definition of intermittency in } \\
\text { the "Methods" section. }\end{array}$
\end{tabular}

27 percent variance explained; Reynolds and others, 2015). More details of this modeling approach are included in Reynolds and others (2015).

\section{Model Projection to Ungaged Streams}

To project each flow metric to ungaged reaches in the Upper Colorado River Basin, we used the environmental variables for each stream raster cell in the basin to predict flow variables across the stream network. We used the "predict" function of R's "raster" package (R Development Core Team, 2013) which uses the independent (environmental) variable data and the associated fitted model to predict a given flow metric at each stream raster cell. Because our random forest models were trained on streamgage data from small streams, we filtered out all stream cells in our projection maps with a drainage area greater than 4,000 square kilometers or approximately $5^{\text {th }}$ order and greater streams. We repeated this process for each flow metric except base flow, which had poor model performance, and zero-flow months, which is not amenable to projection since its units are in months per record (table 1, Reynolds and others, 2015).

\section{Predicting Streams Threatened with Intermittency}

Last, we used the random forest models built in the "Model Development" section described above to predict which streams are currently perennial or only rarely intermittent and threatened to become intermittent under drier climate conditions. Reynolds and others (2015) used conditional inference tree models to show that stream intermittency was best predicted by the streamflow metrics minimum flow $\mathrm{CV}$ and specific mean daily flow with the thresholds of 230 percent minimum flow $\mathrm{CV}, 61.84$ percent minimum flow $\mathrm{CV}$, and 0.096 specific mean daily flow as particularly important thresholds for differentiating streams (Reynolds and others, 2015). Streams that had less than 61.84 percent minimum flow CV were perennial streams. Streams that had greater than 230 percent minimum flow CV were strongly intermittent streams. These first two groups of streams are unlikely to shift from their current hydrology of perennial or strongly intermittent despite a drier climate; however, our conditional inference tree indicated that streams between 61.84 and 230 percent minimum flow $\mathrm{CV}$, and less than 0.096 specific mean daily flow were moderately dry streams, which included a mix of weakly intermittent and perennial streams (Reynolds and others, 2015). Because this set of streams includes perennial and weakly intermittent streams, we hypothesize that these streams are threatened to become intermittent under a drier climate. We used our projected raster datasets of minimum flow $\mathrm{CV}$ and specific mean daily flow to highlight streams that met this criteria (between 61.84 and 230 percent minimum flow $\mathrm{CV}$ and less than 0.096 specific mean daily flow) in the Upper Colorado River Basin and suggest that these streams will be most threatened to shift flow regimes under drier climate conditions. 
Table 2. Environmental variables used to predict flow metrics on gaged streams in the Upper Colorado River Basin.

[Adapted from Falcon (2011). See Falcone (2011) for more explanation of the variables. sq. km, square kilometer; NHDPlus, National Hydrography Dataset Plus; m, meter; cm, centimeter; km, kilometer; mm/yr, millimeter per year; 100's ft-tonf-in/ac/hr/yr, hundreds of feet times ton-force times inches per acre per hour per year; n/a, not applicable; NLCD, National Land Cover Database]

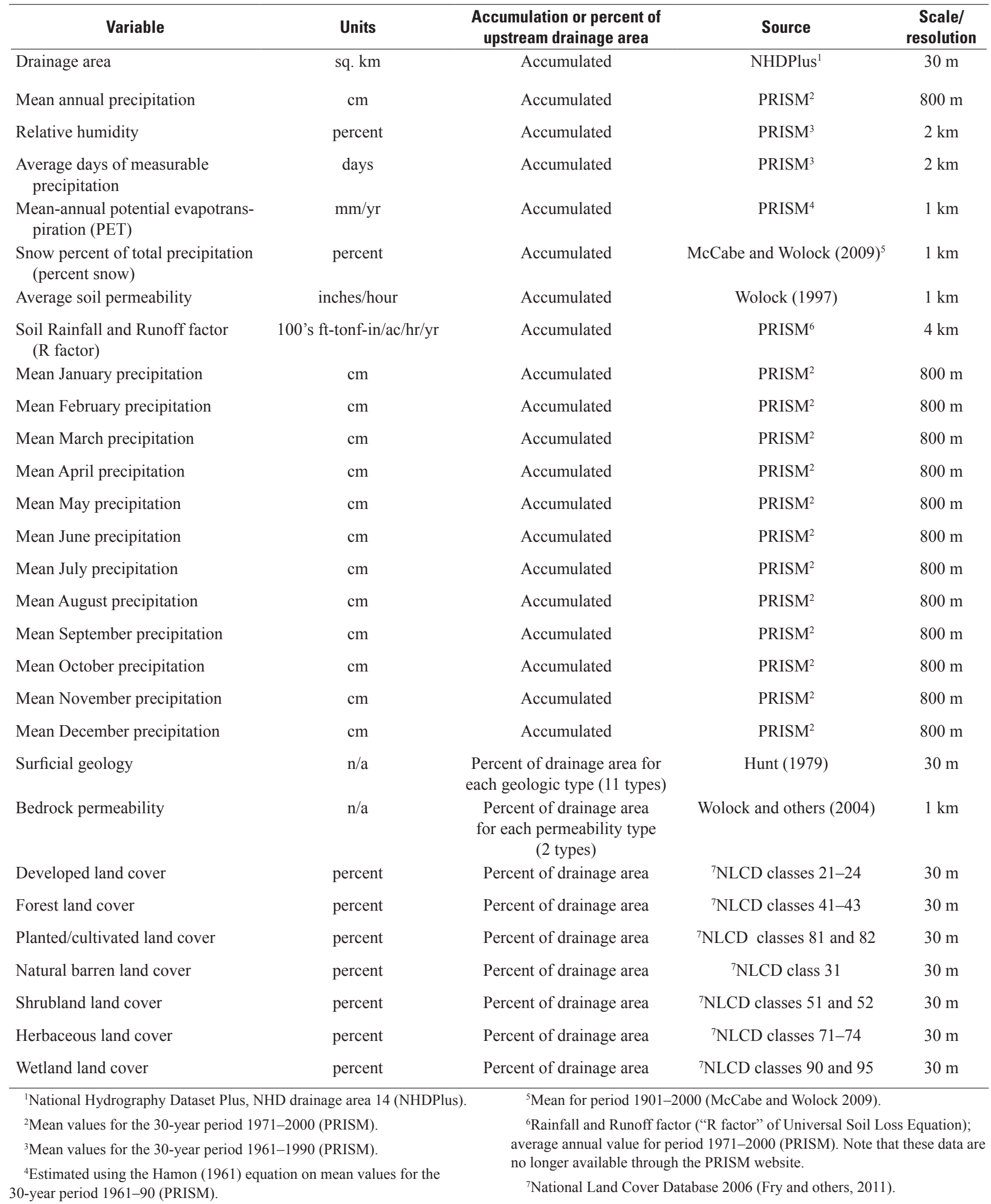




\section{Results and Data Products}

The random forest models we used to project flow metrics to small, ungaged streams varied in model performance between 45.3- and 82.55-percent variance explained (table 3).

We successfully projected low flow metrics to small, ungaged reaches across the Upper Colorado River Basin using random forest models developed in Reynolds and others (2015) and described above in the "Methods" section. We produced seven flow metric datasets, one for each modeled flow metric (tables 3 and 4), for small stream reaches across the Upper Colorado River Basin. An example of the dataset products is shown in figure 2 . We produced an eighth dataset showing modeled intermittency status for each stream reach, including streams that are potentially threatened with intermittency because of drier conditions (fig. 3). The eight geospatial datasets included in this Data Series are summarized in the "Accompanying Data Products" section below.

Table 3. Results of random forest models using environmental variables to predict streamflow metrics.

[Adapted from Reynolds and others (2015). See table 1 for definitions of streamflow metrics. See table 2 for definitions of predictor variables. P-value, [a measure of the strength or statistical significance of a relation; smaller p-values $(<0.01)$ indicate stronger relations]; PET, potential evapotranspiration; $<$, less than; $\mathrm{CV}$, coefficient of variation; R factor, Rainfall and Runoff factor; OOB, out-of-bag; n/a, not applicable]

\begin{tabular}{|c|c|c|c|}
\hline Streamflow metric & Top five predictor variables & $\begin{array}{l}\text { Variance ex- } \\
\text { plained }\end{array}$ & P-value \\
\hline $\begin{array}{l}\text { Specific mean daily } \\
\quad \text { flow }\end{array}$ & $\begin{array}{l}\text { April precipitation, percent forest land cover, average days of measurable precipita- } \\
\text { tion, average annual basin precipitation, and mean-annual PET }\end{array}$ & 82.55 percent & $<0.001$ \\
\hline $\begin{array}{l}\text { Frequency of low } \\
\quad \text { flow pulses }\end{array}$ & $\begin{array}{l}\text { February precipitation, June precipitation, PET, May precipitation, and December } \\
\text { precipitation }\end{array}$ & 50.3 percent & $<0.001$ \\
\hline 7-day minimum & $\begin{array}{l}\text { Drainage area, August precipitation, October precipitation, September precipitation, } \\
\text { and January precipitation }\end{array}$ & 49.4 percent & $<0.001$ \\
\hline $\begin{array}{l}\text { Zero-flow days per } \\
\text { year }\end{array}$ & $\begin{array}{l}\text { Percent snow, December precipitation, February precipitation, } R \text { factor, and November } \\
\text { precipitation }\end{array}$ & 45.3 percent & $<0.001$ \\
\hline Intermittency & $\begin{array}{l}\text { Percent barren land cover, drainage area, PET, June precipitation, and November } \\
\text { precipitation }\end{array}$ & $\begin{array}{l}\mathrm{OOB}^{1} \text { error rate- } \\
20 \text { percent }\end{array}$ & $\mathrm{n} / \mathrm{a}$ \\
\hline
\end{tabular}

${ }^{1}$ The OOB error rate is a cross-validation measure calculated by classification random forests. Better models have lower OOB error rates. See Cutler (2007) for details. 
Table 4. Geospatial datasets of projected streamflow metrics and threatened intermittency status in the Upper Colorado River Basin

[Geospatial datasets are available at http://dx.doi.org/10.3133/ds974. See table 1 for streamflow metric definitions. See table 2 for predictor variable definitions. Flow metrics were predicted by random forest models built using 115 streamgage sites across the Upper Colorado River Basin as training data and climate, land cover, and geology variables as predictor variables. CV, coefficient of variation]

\begin{tabular}{|c|c|c|c|}
\hline Mapped unit & File name & Data type & Description \\
\hline $\begin{array}{l}\text { Specific mean } \\
\text { daily flow }\end{array}$ & SpMeanFlow.tif & Raster & $\begin{array}{l}\text { Predicted specific mean annual flow for small streams in the Upper Colorado River } \\
\text { Basin stream network under historic hydrologic conditions. Values shown on the } \\
\text { map are specific mean flow multiplied by } 1,000 \text {. Nonstream cells in the raster are } \\
\text { represented by NoData cells. }\end{array}$ \\
\hline $\begin{array}{l}\text { Frequency of low- } \\
\text { flow pulses }\end{array}$ & FreqLowPulse.tif & Raster & $\begin{array}{l}\text { Predicted frequency of low pulse events for small streams in the Upper Colorado } \\
\text { River Basin stream network under historic hydrologic conditions. Values shown } \\
\text { on the map are low flow frequency (events/year) multiplied by 1,000. Nonstream } \\
\text { cells in the raster are represented by NoData cells. }\end{array}$ \\
\hline $\begin{array}{l}\text { Minimum flow } \\
\text { CV }\end{array}$ & MinFlowCV.tif & Raster & $\begin{array}{l}\text { Predicted minimum flow CV for small streams in the Upper Colorado River Basin } \\
\text { stream network under historic hydrologic conditions. Values shown on the map } \\
\text { are minimum flow CV multiplied by } 100 \text {. Nonstream cells in the raster are repre- } \\
\text { sented by NoData cells. }\end{array}$ \\
\hline $\begin{array}{l}\text { Specific minimum } \\
\text { flow }\end{array}$ & SpMinFlow.tif & Raster & $\begin{array}{l}\text { Predicted specific mean annual minimum flow for small streams in the Upper Colo- } \\
\text { rado River Basin stream network under historic hydrologic conditions. Values } \\
\text { shown on the map are specific minimum flow multiplied by } 10,000 \text {. Nonstream } \\
\text { cells in the raster are represented by NoData cells. }\end{array}$ \\
\hline $\begin{array}{l}\text { Zero-flow days } \\
\text { per year }\end{array}$ & ZeroFlowDays.tif & Raster & $\begin{array}{l}\text { Predicted number of zero-flow days per year (days/year) for small streams in the } \\
\text { Upper Colorado River Basin stream network under historic hydrologic condi- } \\
\text { tions. Zero-flow day values shown on the map are not modified by any multiplier. } \\
\text { Nonstream cells in the raster are represented by NoData cells. }\end{array}$ \\
\hline
\end{tabular}



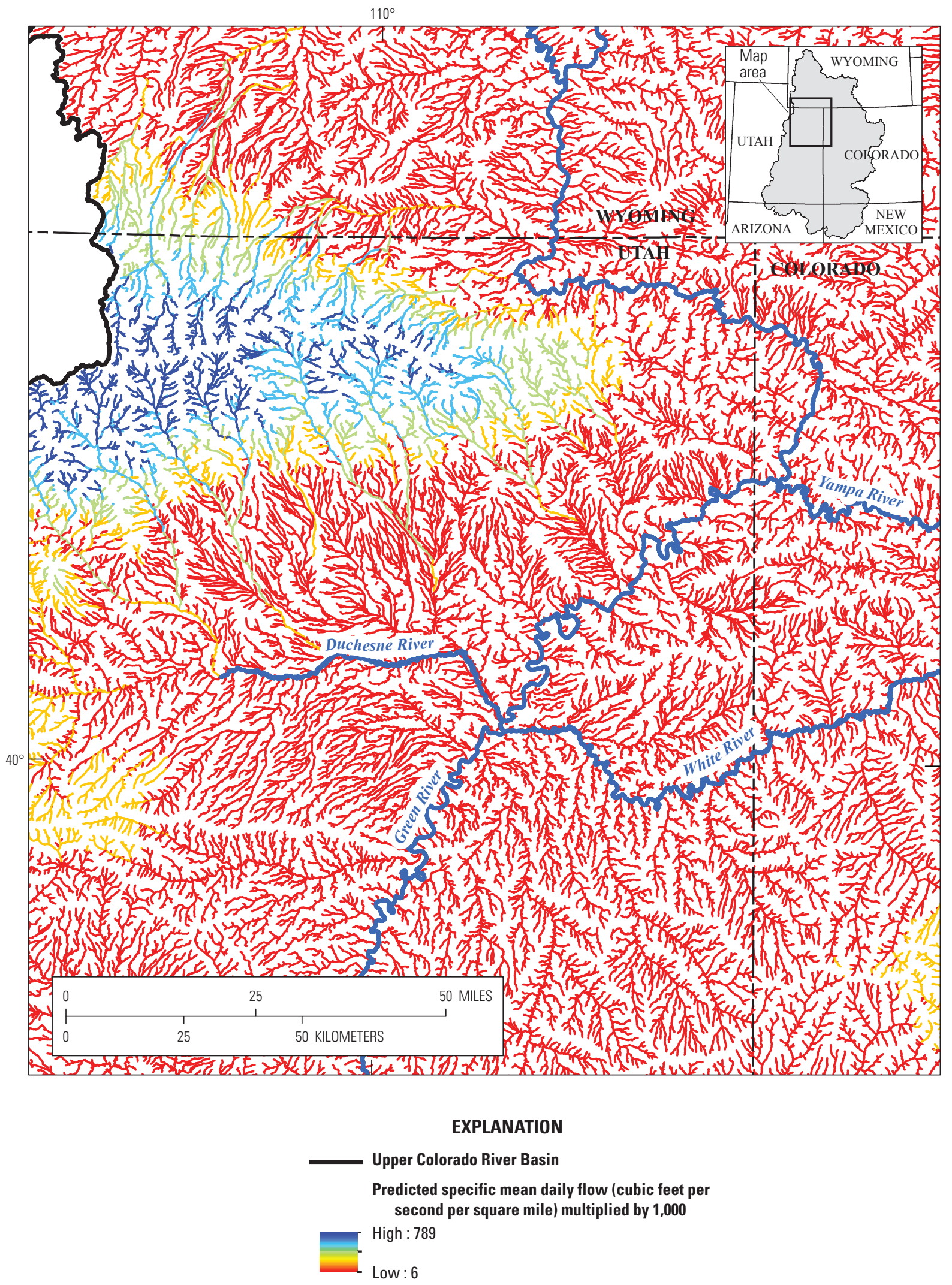

Figure 2. Predicted values of specific mean daily flow multiplied by 1,000 for small streams in a small area of the Upper Colorado River Basin. 


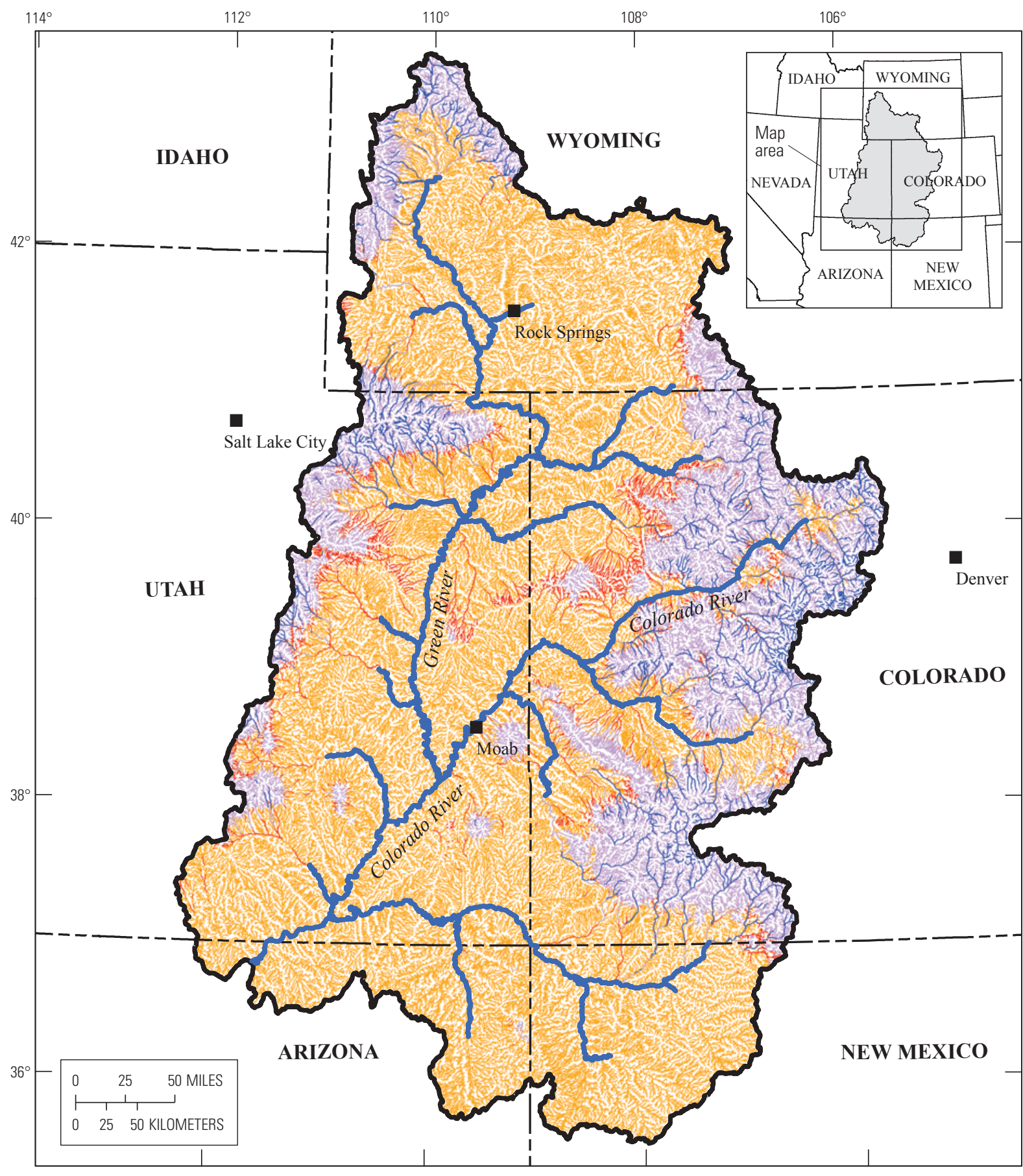

EXPLANATION

Upper Colorado River Basin

Intermittency status

Perennial (minimum flow cofficient of variation [CV] less than 61.84 percent)

Threatened with intermittency (minimum flow CV between 61.84 percent and 230.32 percent and specific mean annual flow less than 0.096)

_ Intermittent (minimum flow CV between 61.84 percent and 230.32 percent and specific mean annual flow greater than 0.096)

Strongly intermittent (minimum flow CV greater than 230.32 percent)

Figure 3. Predicted intermittency status of small stream reaches based on current streamflow metrics in the Upper Colorado River Basin: perennial, threatened with intermittency, intermittent, or strongly intermittent. 


\section{Disclaimers}

Although these data have been processed successfully on a computer system at the U.S. Geological Survey, no warranty expressed or implied is made regarding the display or utility of the data on any other system, or for general or scientific purposes, nor shall the act of distribution constitute any such warranty. The U.S. Geological Survey shall not be held liable for improper or incorrect use of the data described and (or) contained herein.

\section{Summary}

We developed geospatial datasets of projected mean and low streamflow metrics on small streams in the Upper Colorado River Basin using random forest statistical models. Our models varied in performance and explained about $45-85$ percent of variance for each flow metric. These datasets can help scientists, land managers, and policymakers understand current hydrology in the Upper Colorado Basin and to make informed decisions regarding water resources. With knowledge of which streams are likely to undergo significant drying in the future, land managers and scientists can more effectively plan for drying conditions, human water uses, and the consequences for stream dependent ecosystems.

\section{Accompanying Data Products}

See table 4 in the "Results and Data Products" section for geospatial dataset file names and descriptions. Geospatial datasets are available at http://dx.doi.org/10.3133/ds974.

\section{References Cited}

Carlisle, D.M., Falcone, J.A., Wolock, D.M., Meador, M.R., and Norris, R.H., 2010, Predicting the natural flow regime-Models for assessing hydrological alteration in streams: River Research and Applications, v. 26, no. 2, p. 118-136. [Also available at http://dx.doi.org/10.1002/ rra.1247.]

Cayan, D.R., Maurer, E.P., Dettinger, M.D., Tyree, Mary; and Hayhoe, Katharine, 2008, Climate change scenarios for the California region: Climatic Change, v. 87, no. 1, p. S21-S42. [Also available at http://dx.doi.org/10.1007/ s10584-007-9377-6.]
Christensen, N.S., and Lettenmaier, D.P., 2007, A multimodel ensemble approach to assessment of climate change impacts on the hydrology and water resources of the Colorado River Basin: Hydrology and Earth System Sciences, v. 11, no. 4, p. 1417-1434. [Also available at http://dx.doi.org/10.5194/ hess-11-1417-2007.]

Clow, D.W., 2010, Changes in the timing of snowmelt and streamflow in Colorado-A response to recent warming: Journal of Climate, v. 23, no. 9, p. 2293-2306. [Also available at http://dx.doi.org/10.1175/2009JCLI2951.1.]

Colorado Water Conservation Board, 2012, Colorado River water availability study: Phase 1 report, 189 p. [Also available at http://cwcbweblink.state.co.us/weblink/0/ doc/158319/Electronic .aspx? searchid=78f0eafa-0b8f-4d8a9ff3-faf67cc82f52]

Cutler, D.R., Edwards, T.C., Beard, K.H., Cutler, Adele; and Hess, K.T., Gibson, Jacob; and Lawler, J.J., 2007, Random forests for classification in ecology: Ecology, v. 88, no. 11, p. 2783-2792. [Also available at http://dx.doi. org/10.1890/07-0539.1.]

Das, Tapash; Pierce, D.W., Cayan, D.R., Vano, J.A., and Lettenmaier, D.P., 2011, The importance of warm season warming to western US streamflow changes: Geophysical Research Letters, v. 38, no. 23, p. L23403. [Also available at http://dx.doi.org/10.1029/2011GL049660.]

Ely, L.L., 1997, Response of extreme floods in the southwestern United States to climatic variations in the late Holocene: Geomorphology, v. 19, no. 3-4, p. 175-201. [Also available at http://dx.doi.org/10.1016/S0169-555X(97)00014-7.]

Eng, K., Carlisle, D.M., Wolock, D.M., and Falcone, J.A., 2013, Predicting the likelihood of altered streamflows at ungauged rivers across the conterminous United States: River Research and Applications, v. 29, no. 6, p. 781-791. [Also available at http://dx.doi.org/10.1002/rra.2565.]

Falcone, J.A., 2011, GAGES-II-Geospatial attributes of gages for evaluating streamflow: U.S. Geological Survey. [Also available at http://water.usgs.gov/lookup/ getspatial?gagesII_Sept2011.]

Fry, J.A., Xian, George; Jin, Suming; Dewitz, J.A., Homer, C.G., Yang, Limin; Barnes, C.A., Herold, N.D., and Wickham, J.D., 2011, Completion of the 2006 National Land Cover Database for the Conterminous United States: Photogrammetric Engineering \& Remote Sensing, v. 77, no. 9, p. 858-864. [Also available at http://www.mrlc.gov/ downloadfile2.php?file=September2011PERS.pdf.]

Gochis, D.J., Brito-Castillo, Luis; and Shuttleworth, W.J., 2006, Hydroclimatology of the North American Monsoon region in northwest Mexico: Journal Of Hydrology, v. 316, no. 1-4, p. 53-70. [Also available at http://dx.doi. org/10.1016/j.jhydrol.2005.04.021.] 
Hamon, W.R., 1961, Estimating potential evapotranspiration: Journal of the Hydraulics Division, Proceedings of the American Society of Civil Engineers, v. 87, p. 107-120.

Heasley, J., 2006, Hydrologic Index Tool (ver. 1.46): U.S. Geological Survey.

Hereford, Richard; and Webb, R.H., 1992, Historic variation of warm-season rainfall, southern Colorado Plateau, southwestern U.S.A.: Climatic Change, v. 22, no. 3, p. 239-256. [Also available at http://dx.doi.org/10.1007/BF00143030.]

Hunt, C.D., 1979, National atlas of the United States of America-Surficial geology: U.S. Geological Survey, v. NAC-P-0204.

Jaeger, K.L., Olden, J.D., and Pelland, N.A., 2014, Climate change poised to threaten hydrologic connectivity and endemic fishes in dryland streams: Proceedings of the National Academy of Sciences of the United States of America, v. 111, no. 38, p. 13894-13899. [Also available at http://dx.doi.org/10.1073/pnas.1320890111.]

Jerla, C., Prairie, J., and Adams, P., 2012, Colorado River Basin water supply and demand study report: U.S. Department of Interior, Bureau of Reclamation.

Leppi, J.C., DeLuca, T.H., Harrar, S.W., and Running, S.W., 2011, Impacts of climate change on August stream discharge in the Central-Rocky Mountains: Climatic Change, v. 112, no. 3, p. 997-1014. [Also available at http://dx.doi. org/10.1007/s10584-011-0235-1.]

McCabe, G.J., and Wolock, D.M., 2009, Recent declines in western U.S. snowpack in the context of twentieth-century climate variability: Earth Interactions, v. 13, no. 12, p. 1-15. [Also available at http://dx.doi.org/10.1175/2009EI283.1.]

Milly, P.C.D., Dunne, K.A., and Vecchia, A.V., 2005, Global pattern of trends in streamflow and water availability in a changing climate: Nature, v. 438, no. 7066, p. 347-350. [Also available at http://dx.doi.org/10.1038/nature04312.]

Murphy, J.C., Knight, R.R., Wolfe, W.J., and Gain, W.S., 2012, Predicting ecological flow regime at ungaged sitesA comparison of methods: River Research and Applications, v. 29, no. 5, p. 660-669. [Also available at http://dx.doi. org/10.1002/rra.2570.]

Murphy, M.A., Evans, J.S., and Storfer, A., 2010, Quantifying Bufo boreas connectivity in Yellowstone National Park with landscape genetics: Ecology, v. 91, no. 1, p. 252-261.

NHDPlus, 2010, National Hydrography Dataset Plus Version 1: Horizon Systems Corporation. [Available online at http://www.horizon-systems.com/nhdplus/.]
Olden, J.D., and Poff, N.L., 2003, Redundancy and the choice of hydrologic indices for characterizing streamflow regimes: River Research and Applications, v. 19, no. 2, p. 101-121. [Also available at http://dx.doi.org/10.1002/rra.700.]

Poff, N.L., and Ward, J.V., 1989, Implications of streamflow variability and predictability for lotic community structure - A regional analysis of streamflow patterns: Canadian Journal of Fisheries and Aquatic Sciences, v. 46, no. 10, p. 1805-1818. [Also available at http://dx.doi.org/10.1139/ f89-228.]

PRISM Climate Group, Oregon State University, 2008, [Available at http://prism.oregonstate.edu, 2008]

R Development Core Team, 2013, R: A language and environment for statistical computing: R Foundation for Statistical Computing, Vienna, Austria. [Also available at http:// www.r-project.org/.]

Reynolds, L.V., Shafroth, P.B., and Poff, N.L., 2015, Modeled intermittency risk for small streams in a North American river basin under climate change: Journal of Hydrology, v. 523, p. 768-780. [Also available at http://dx.doi. org/10.1016/j.jhydrol.2015.02.025.]

Seager, Richard; Ting, Mingfang; Li, Cuihua; Naik, Naomi; Cook, Ben; Nakamura, Jennifer; and Liu, Haibo, 2013, Projections of declining surface-water availability for the southwestern United States: Nature Climate Change, v. 3, no. 5, p. 482-486. [Also available at http://dx.doi. org/10.1038/nclimate1787.]

Teng, Jin; Vaze, Jai; Chiew, F.H.S., Wang, Biao; and Perraud, Jean-Michel, 2012, Estimating the relative uncertainties sourced from GCMs and hydrological models in modeling climate change impact on runoff: Journal of Hydrometeorology, v. 13, no. 1, p. 122-139. [Also available at http:// dx.doi.org/10.1175/JHM-D-11-058.1.]

Wolock, D.M., 1997, STATSGO soil characteristics for the conterminous United States: U.S. Geological Survey OpenFile Report 97-656. [Also available at http://pubs.er.usgs. gov/publication/ofr97656.]

Wolock, D.M., Winter, T.C., and McMahon, Gerard, 2004, Delineation and evaluation of hydrologic-landscape regions in the United States using geographic information system tools and multivariate statistical analyses: Environmental Management, v. 34, no. 1, p. S71-S88. [Also available at http://dx.doi.org/10.1007/s00267-003-5077-9. 
Publishing support provided by:

Rolla Publishing Service Center

For more information concerning this publication, contact:

Director, USGS Fort Collins Science Center

2150 Centre Avenue, Building C

Fort Collins, CO 80526-8118

(970) 226-9100

Or visit the Fort Collins Science Center Web site at: https://www.fort.usgs.gov/ 

